\title{
PELATIHAN APLIKASI SPEECHACE UNTUK PENINGKATAN KEFASIHAN BERBAHASA INGGRIS PADA GURU - GURU MTs AI JAM'IYATUL WASHLIYAH DALU X A KABUPATEN DELI SERDANG SUMATERA UTARA
}

\author{
Wariyati $^{1)}$, Sujarwo ${ }^{2)}$, Arti Dwi Maulia ${ }^{3)}$ \\ Universitas Muslim Nusantara Al Washliyah Al Washliyah ${ }^{1)}$ \\ Universitas Muslim Nusantara Al Washliyah Al Washliyah ${ }^{2)}$ \\ Universitas Muslim Nusantara Al Washliyah Al Washliyah ${ }^{3)}$ \\ nengyaticokro12@yahoo.com
}

\begin{abstract}
ABSTRAK
Tujuan pengabdian kepada masyarakat adalah membantu guru - guru MTs Al Jam'iyatul Washliyah Dalu X A Kabupaten Deli Serdang dalam meningkatkan kualitas dan level kefasihan dalam pengucapan bahasa Inggris dimana kualitas kefasihan merujuk kepada penutur asli atau native speaker. Penggunaan aplikasi speechace dapat mendeteksi level kefasihan pengucapan dengan standard kemiripan pada penutur asli. Media ini selain mampu mendeteksi juga dapat mengarahkan dengan ketersidaan contoh pengucapan yang baik dan benar merujuk pada kefasihan sempurna. Semakin fasih pengucapan maka akan semakin baik kualitas penuturan dalam berbahasa Inggris. Kefasihan juga berdampak pada kualitas kemampuan siswa mendengar (listening) sehingga butuh pelatihan khusus untuk guru dalam meningkatkan level kefasihan. Karena pembelajar sebuah bahasa adalah imitator atau peniru, maka jika gurunya sangat berkualitas sudah tentu murid juga memiliki kualitas yang tak jauh berbeda. Tujuan khusus dengan mensosialisasikan penggunaan media pembelajaran atau berbasis web internet melalui aplikasi speechace secara online untuk meningkatkan daya saing didunia kerja. Penerapan yang digunakan dalam pelaksanaan kegiatan pengabdian kepada masyarakarat pada MTs Al Jam'iyatul Washliyah Dalu X A dengan mensosialisasikan pengoperasian aplikasi digital speechace berupa: (1) Pemilihan tingkat kefasihan dan kajian kosa kata ataupun ungkapan berbahasa Inggris. (2) Acuan dan standard kefasihan (3) Pengujian tingkat kefasihan guru. Pengabdian dilaksanakan di MTs Al Jam'iyatul Washliyah Kabupaten Serdang Bedagai. Kefasihan dalam pelafalan Bahasa Inggris sangat mempengaruhi kualifikasi skill dalam berbahasa Inggris mengacu kepada standarisasi penutur asli (native speaker). Urgensi yang harus dipenuhi adalah daya saing yang amat tinggi didunia kerja atau dunia perkuliahan yang berstandard Internasional. Kualitas Bahasa Inggris yang baik akan member kontribusi menunjang untuk meraih beasiswa pendidikan baik bagi guru dan siswa, begitu juga didunia kerja untuk menjemput kesusksesan yang gemilang.
\end{abstract}

Kata kunci: kefasihan, aplikasi, Bahasa Inggris

\begin{abstract}
The aim of community service is to help MTs Al Jam'iyatul Washliyah Dalu X A teachers in Deli Serdang Regency in improving the quality and level of fluency in English pronunciation where fluency quality refers to native speakers. The use of the speechace application can detect the level of fluency of pronunciation with the standard of similarity in native speakers. Apart from being able to detect this media, it can also lead to the presence of examples of good and correct pronunciation, referring to perfect fluency. The more fluent the pronunciation, the better the quality of speaking in English. Fluency also has an impact on the quality of students' listening skills so special training is needed for teachers to improve their level of fluency. Because learners of a language are imitators or imitators, if the teacher is of very high quality, of course students also have qualities that are not much different. The specific objective is to socialize the use of learning media or web-based internet through online speechace applications to improve competitiveness in the world of work. The application used in the implementation of community service activities in Al Jam'iyatul Washliyah MTs Dalu X A by socializing the operation of digital speechace applications in the form of: (1) Selection of the level of fluency and study of vocabulary or expressions in English. (2) Reference and standard of fluency (3) Testing the level of teacher fluency. Dedication was carried out at MTs Al Jam'iyatul Washliyah, Serdang Bedagai Regency. Fluency in English pronunciation greatly influences the qualification of skills in English
\end{abstract}


referring to the standardization of native speakers. The urgency that must be fulfilled is very high competitiveness in the world of work or in the world of international standard lectures. A good quality of English will contribute to supporting the achievement of educational scholarships for both teachers and students, as well as in the world of work to pick up brilliant success.

Keyword: fluency, application, English

\section{PENDAHULUAN}

Kegiatan pelatihan dan pendampingan tentang pentingnya ketepatan pelafalan Bahasa Inggris berstandar kepada penutur asli (native speaker). Penggunaan aplikasi ini dapat menjadi solusi untuk mendeteksi tingkat kefasihan dan ketepatan dalam pelafalan (pronunciation) or articulation dalam bahasa Inggris. Merujuk kepada standard penutur asli amatlah kecil kemungkinan untuk siswa selaku pembelajar bahasa Inggris untuk bertemu langsung dengan penutur asli untuk mendeteksi ketepatan dalam pelafalan berbahasa Inggris. Oleh sebab itu sosialisasi penggunaan aplikasi ini sangat tepat menjadi solusi untuk menggantikan kehadiran penutur asli dalam menganalisa dan mengevaluasi ketepatan berbahasa. Aplikasi ini tidak hanya untuk mengklasifikasi level kualifikasi dan ketepatan berbahasa tapi juga memiliki panduan ketepatan pengucapan.

\section{METODE PELAKSANAAN}

Mekanisme pelaksanaan kegiatan pengabdian pada masyarakat meliputi tahapan-tahapan berikut:

1. Perekrutan peserta.

2. Konsultasi dengan ahli.

3. Pembekalan (coaching) kepada pemateri dosen dan mahasiswa.

4. Penyiapan sarana dan prasarana terkait dengan pelaksanaan kegiatan

Materi persiapan dan pembekalan kepada mahasiswa mencakup:
Sesi Pembekalan/Coaching

1.Peran mahasiswa dalam Pengabdian oleh dosen.

2. Panduan dan pelaksanaan program pengabdian oleh dosen.

3. Perancangan model kegiatan melalui Pelatihan dan Pendampingan terkait dengan penggunaan media online dan pelafalan Bahasa Inggris serta kefasihannya.

Dalam melaksanakan kegiatan ini adapun metode yang dilakukan sebagai berikut:

Metode yang digunakan dalam pencapaian tujuan tersebut adalah pemberdayaan siswa dan guru-guru melalui pelatihan dan pendampingan. Metode ini digunakan dalam melakukan pemberdayaan masyarakat sekolah seperti kepala sekolah, guru, dan siswa di lingkungan MTs Al Jam'iyatul Washliyah. Pelatihan dan pendampingan disertai praktek berupa simulasi (contoh kasus) yang akan dilakukan oleh mahasiswa bersamasama dengan kelompok sasaran dan berelaborasi dengan semua pihak sekolah serta dosen pelaksana.

Proses pelaksanaan

keberlanjutan program ini yakni pendampingan maupun pemberdayaan masyarakat lingkungan sekolah dilakukan mahasiswa dan dosen selama program Pengabdian yang intensif dan terarah serta tercapai tujuan dari permasalahan yang dialami sekolah. Penempatan mahasiswa pada berbagai program dalam rangka pemetaan terhadap berbagai jenis kesalahan 
pada pengunaan bahasa di ruang publik yang dibuat oleh pihak sekolah serta solusi dan alternatifnya.

Kegiatan ini dilaksanakan bagi guru - guru MTs Al Jam'iyatul Washliyah Desa Dalu X A Tanjung Morawa. Lokasi Pengabdian sangat mudah dicapai karena berada pada jalan lintas menuju Bandara Kualanamo. Program pengabdian ini dengan menerapkan pembelajaran Bahasa Inggris dengan menggunakan aplikasi speechace. Para guru dilatih dengan masing - masing memiliki alat /media plikasi baik menggunakan laptop dengan jaringan internet maupun mobile seluler. Aplikasi didownload kemudian diajarkan cara mengoperasikannya. Kemudian setiap guru dminta untuk menggunakannya. Setiap guru menguji coba kannya berkali - kali sesuai dengan level yang dipilih. Semakin baik nilai yang diperoleh maka para guru (peserta tersebut) dapat melanjutkan pelatihan ke level berikutnya.

Program pelatihan dan pengabdian ini akan semakin signifikan pemerolehan hasilnya jika dialokasikan waktu yang berkelanjutan dan pendampingan secara terus menerus.

\section{HASIL DAN PEMBAHASAN}

Pelatihan dengan program pengabdian masyarakat menerapkan penggunaan aplikasi speechace pada guru - guru MTs Al Jam'iyatul Washliyah memiliki peranan penting dalam membantu para guru untuk mendapatkan kemampuan pelafalan kosa kata Bahasa Inggris secara fasih dan benar. Para guru sangat antusias dalam memparkatekkan penggunaan aplikasi ini mesi dilator belakangi dengan pendidikan beragam diluar bidang Bahasa Inggris.

\section{KESIMPULAN}

Program pengabdian ini memampukan para guru untuk mempelajari pelafalan Bahasa Inggris secara praktis, mudah dan menyenangkan. Seberapa efisiennya hasil dari program pengabdian ini terlihat dari kenaikan pemerolehan score yang sudah dicapai oleh para guru yang semakin meningkat. Keefektifan program ini akan semakin baik bila dilaksanakan secara berkelanjutan sehingga para guru dapat didampingi dan dipantau untuk perkembangan kemampuan kefasihan dalam pelafalan.

\section{REFERENSI}

Anderson,L.W.2001. A Taxonomy forTeaching and Assesing:A Revision of Blooms of Educational Objectives. New York: Longman

Arends, R.I. 2008. Learning to Teach. Seven Editions. New York: McGraw-Hill.

Arikunto,S.2006. Prosedur Penelitian Suatu Pendekatan Praktik.Jakarta: Reineka Cipta.

Ary, D. J. \& Razaviech, H. 1979. Introduction to Research in Education. New York: Holt Rinehart and Winston.

Bogdan, R.C. \& Biklen, S.K. 1992. Qualitative Research for Education: An Introduction to Theories and Methods Limitations of a behavio

Elliot, A. R. (1995). Field language phonology: Field independence, attitude, and the success of formal instruction in Spanish as 
a foreign language. The Modern Language Journal, 79(4), 530542.

Fathurrahman, M.2015. Model Model Pengajaran Inovativ.Editor Nurhidayah. Cetakan 1 Penerbit Ar Ruzz Media. Jogyakarta.

Holzberger, D., Phillip, A.,\& Kunter, M. (2013). How teachers' self efficacy is related to instructional quality: A longitudinal analysis. Journal of Educational Psychology, 105(3), 774-786. Huda, Miftahul.2014. Model - Model Pengajaran dan Pembelajaran: Isu - Isu Metodis dan Paradigmatis. Yogyakarta: Pustaka Belajar.

Joyce, B. Weil, M dan Calhoun, E. 2009. Model of Teaching. India: Prentice Hall

Kaklamaou, D., Pearce, J., \& Nelson, M. (2012). Food Academic: A Qualitative Study. Deparment for Education, 1-23

Keane, D. T. (2012). Leading with Technology. The Australian Educational Leader, 34(2), 44.

Krashen, S.D. (1982). Principle and practice in second language acquisition. New York: Pergamon

Lai, Y.H., Huang, F.F. \& Yang, H. H. (2012). The Effect of Nutrition Education System for Elementary School Students in Nutrition Knowledge. Journal of Oriental Institute of Technology, 32, 115-123.
Lincoini, Y.S \& Guba E.G.1985. Naturalistic Inquiry. Beverly Hills California. Sage Publication, Inc 